\title{
サクランの皮膚保護作用とスキンケアへの応用
}

\author{
正木 $\quad$ 仁, ${ }^{*}, a$ 土井萌子 $b$
}

\section{Function of Sacran as an Artificial Skin Barrier and the Development of Skincare Products}

\author{
Hitoshi Masaki ${ }^{*, a}$ and Moeko Doi ${ }^{b}$ \\ aSchool of Bioscience and Biotechnology, Tokyo University of Technology; 1404-1 Katakura-machi, Hachioji, Tokyo \\ 190-0982, Japan: and ${ }^{b}$ DAITO KASEI KOGYO CO., LTD.; 1-6-28 Akagawa, Asahi-ku, Osaka 535-0005, Japan.
}

(Received August 8, 2018)

\begin{abstract}
Sacran, a large molecular-weight polysaccharide isolated from algae, is composed of 11 types of saccharides, including sulfate and carboxylic acid groups. Because of its unique structure, sacran can form a gel-like sheet in the presence of polyols such as 1,3-butanediol. In addition, those sacran gel-like sheets prevent the evaporation of water and the penetration of chemicals. The results of our previous study suggested that sacran can work as an artificial barrier against external stimuli such as air pollutants which increase the stress on humans. Topically applied sacran was localized at the surface of reconstructed human epidermal equivalents. Those results suggested that sacran inhibits excessive water evaporation from the skin and protects against environmental stimuli by forming an artificial barrier at the skin surface. Then, in a clinical study, we examined the activity of sacran in improving skin problems caused by an impaired epidermal barrier. First, we conducted a use test on a serum formulated with sacran on human volunteers who had impaired skin barrier function. The results showed that sacran provided excellent benefits to improve the maturation of corneocytes. These results suggest that sacran could play an important role in providing optimal skin conditions for keratinocytes to progress through their differentiation.
\end{abstract}

Key words_-sacran; emulsification; corneocyte; skin moisture; barrier function

\section{1. 背 景}

皮膚は私たちの体の最外層に位置する器官であ り，生体内部を外環境から隔離し保護するバリアと して働いている。外環境因子としては，温度，湿度 を始めとして太陽光線が皮膚生理に大きな影響を及 ぼすことはよく知られている。また，近年では PM2.5 を始めとする大気污染物質が皮膚生理に影 響を及ぼす環境因子として注目されている。皮膚は コンクリート造りのような柔軟性のない壁ではな く, これら外環境の変化に物理的にも生理的にも柔 軟に対応する動的インターフェースとして機能して いる。しかしながら，その機能が低下したときに は，環境因子の影響を強く受け大きなダメージを受 けることになる。このような状況を回避するために

${ }^{a}$ 東京工科大学応用生物学部（T190-0982 東京都八王 子市片倉町 1404-1), $b$ 大東化成工業株式会社（广5350005 大阪市旭区赤川 1 丁目 6-28)

*e-mail: masaki@stf.teu.ac.jp

本総説は, 日本薬学会第 138 年会シンポジウム S69 で

発表した内容を中心に記述したものである.
は皮膚保護効果を発揮するスキンケアが大切になる.

$$
\text { スイゼンジノリ [Aphanothece sacrum (Sur.) }
$$

OKADA］は, 日本固有の淡水性の藍藻であり, 江 戸時代より食用として親しまれてきた。これまで, スイゼンジノリは，阿蘇山の岩盤からの湧水が流れ 込む河川がある地域に限定して生育が確認されてい たが, 水質污染によりその生育領域は狭まり, 現在 では熊本県と福岡県の一部でのみスイゼンジノリの 生育が確認されている，淡水に含まれる成分により スイゼンジノリの生育は大きく左右され，生育に係 わる成分の同定はいまだになされていない.このこ とから, スイゼンジノリの養殖は困難な状況にあ り, 近い将来には絶滅の可能性が指摘され絶滅危惧 種に指定されている.

スイゼンジノリは，細胞外マトリックスとしてサ クラン（sacran）と呼ばれる高分子多糖体を合成し ている. サクランは分子量 $29 \mathrm{MDa}$, 分子鎖長 $10 \mu \mathrm{m}$ 以上の超高分子多糖体であり, 約 11 種類の 糖から構成される。 その構成糖に硫酸基やカルボキ シル基を有することからアニオン性多糖と考えられ 
ている. ${ }^{1)}$

これまで，筆者らはスキンケアの観点からサクラ ンの物理化学的特性について研究し, その効果をヒ

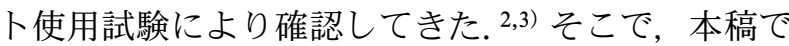
は，サクランのユニークな物理化学的特性による皮 膚保護効果を中心としたスキンケアへの展開につい て紹介する.

\section{2. 皮膚の基本的な構造と機能}

2-1. 表皮の構造 皮膚は大きく外側から表 皮, 真皮, 皮下組織に分けられる。これらの中でも 皮膚バリア機能に大きく関与しているのは表皮であ る. 表皮は主に表皮細胞により構成され，4つの層 が存在する，これらの層は，最表面から角層（stratum corneum), 顆粒層 (stratum granulosum), 有 棘層 (stratum spinosum)，基底層 (stratum basale) と呼ばれ，各層は角層細胞 (corneocyte)，顆粒細 胞，有棘細胞，基底細胞により構成されている。 こ れら各細胞は基底細胞から派生し，基底細胞から分 裂した娘細胞が角化（分化）に伴って，各層を構成 する細胞へ変化していく.

2-2. 角層の構造 角層を構成する角層細胞は 生命活動を停止した死細胞であり，本来，細胞に存 在する細胞内小器官や核は消失している，角層細胞 内部は一定のパターンに整列したケラチンフィラメ ント（トノフィラメント）によって，満たされてい る.さらに, 細胞膜もリン脂質二重膜ではなく, involucrin, loricrin, filaggrin, small proline-rich protein がトランスグルタミナーゼ-1（TGM-1）により 架橋された構造的に強度の高い cornified cell envelope（CE）によって被われている. ${ }^{4}$ また，その外 側には， $\omega$-ヒドロキシセラミドがエステル結合を

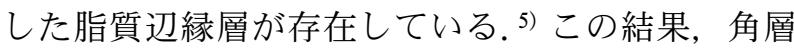
は機械的，化学的にも強度が高い疎水的な特性を獲 得する．角層細胞間にはセラミド，脂肪酸，コレス テロールで構成される脂質二重膜が積み重なってラ メラ構造体を構成している.このラメラ構造体は, 表皮のバリア機能発現に貢献している.

2-3. 皮膚のバリア機能外部からの刺激に対 するバリア機能は，異物に対する物理的な障壁とし て機能するバリア機能と，細菌やウイルスなどの病 原体に対して生理学的に機能するバリア機能に分け ることができる.

このバリア機能に関係しているのが角層である.
角層細胞とその細胞間に存在する脂質ラメラ構造 体，そして顆粒細胞間に存在するタイトジャンク ション (tight junction) ${ }^{6)}$ が物理的な障壁として機 能する. 一方, 抗菌ペプチドが生理学的バリアとし て機能する. 角層の層数は, 体の部位によっても異 なるが 10 層から 20 層存在し， $20 \mu \mathrm{m}$ 程度の厚みが ある．前述のように，角層の障壁は，外部からの化 学物質の体内への侵入を抑制し，分子量 18 程度の 水分子の侵入でさえ制限する機能がある。この物理 的なバリア機能は物質に限るものではなく, 紫外線 のような電磁波に対するバリアとしても働く. 7$)$

皮膚バリア機能低下は, 外部からの物質の生体内 部への侵入を容易とする。この結果，アトピー性皮 膚炎（atopic dermatitis; AD）のようなアレルギー 疾患が発症する。.さらに，皮膚バリア機能の低下は 皮膚を乾燥状態に誘導する。一般的に皮膚の保湿状 態を表すパラメーターとして皮膚表面水分量と経表 皮水分蒸散量（trans-epidermal water loss; TEWL) がある。皮膚表面水分量には TEWL が大きく関与 するが，それ以外に角層内部に存在する天然保湿因 子（natural moisturizing factor）による水分保持が 関与している。 また，皮膚の保湿状態は表皮細胞の 分化の過程にも大きく影響を及ぼす. ${ }^{8}$

表皮細胞の分化状態は角層細胞由来のパラメー ターを用いて議論される。一般的に用いられる角層 細胞由来パラメーターには角層細胞面積, 多重剥離 度，遊離 $\mathrm{SH}$ 基と $\mathrm{SS}$ 基の比（SH/SS），カルボ二 ルタンパク (carbonyl protein; CP), 炎症性サイト カインであるインターロイキン 1 レセプターアンタ ゴニストとインターロイキン- $1 \alpha$ の比（IL-1RA/IL1 $\alpha$ ）がある. 各パラメーターが示す角層分化状態 及び表皮内部状態の解釈は以下の通りになる。

2-4. 角層細胞由来パラメーターの意味 角層 細胞面積は角層細胞が皮膚表面に滞留する時間を示 すパラメーターである。つまり，角層細胞面積は角 層のターンオーバー速度を表す指標と考えられてい る。一般に皮膚内部に弱い炎症反応が存在している 場合は，ターンオーバー速度が速くなり，その結 果，角層細胞面積は小さくなる。一方，老化した皮 膚のように代謝機能の低下した皮膚ではターンオー バー速度は遅くなり角層細胞面積は大きくなる，角 層細胞面積から皮膚代謝及び皮膚内部での微弱炎症 を議論することができる. ${ }^{9}$ 
また，多重剥離の高い頻度が乾燥性皮膚でよく観 察される，多重剥離は，テープストリップによる角 層採取時に本来であれば角層細胞が一層ずつ剥離さ れてくるが，これが多層に重なって剥離される状態 のことを言う。角層細胞はコルネオデスモソームに より接着されており, カリクレインやカテプシン $\mathrm{D}$ などのタンパク分解酵素がコルネオデスモソー ムを消化することにより角層の落屑が進行す る. ${ }^{10,11)}$ 乾燥肌で多く観察される多重剥離のメカ二 ズムは解明されていないが，角層内水分の分布によ る角層下層部位でのタンパク分解酵素の不均一な活 性化が原因となり部分的なコルネオデスモソームの 消化が進行している可能性が考えられる.

遊離 $\mathrm{SH}$ 基と $\mathrm{SS}$ 基の比（SH/SS）は，角層細胞 の成熟度を表す指標と考えられる，表面からの角層 内深部から表面に向けて, SH/SS 比率が低下して くる。これは，角層細胞が表面に現れてくるに従い 遊離 SH 基がスルホヒドリルオキシダーゼにより

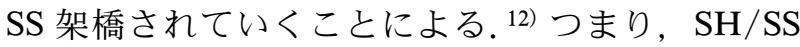
比が高い角層細胞が，角層表面に現れてくることは 角層の成熟度が低いことを示している，さらに，角 層細胞の成熟度を示すパラメーターとしては CE の 状態を反映するインボルクリンの染色とナイルレッ ドの染色の比がある. ${ }^{13)} \mathrm{CE}$ は種々の分化関連タン パクが TGM-1 により架橋されて形成される。分化 関連タンパクの 1 つにインボルクリンがあり，イン ボルクリンが TGM-1 により完全に CE に組み込ま れることによりインボルクリンの免疫染色性は消失 する．CE には脂質辺縁層が存在することから，油 溶性の蛍光色素であるナイルレッドに染色される. このナイルレッドによる染色強度によりインボルク リンの染色強度を規格化した值がインボルクリンの 染色とナイルレッドの染色の比となる。つまり，こ の值が大きくなると CE の形成が不全となり, 角層 細胞の成熟度が低いことを示している.

皮膚内部では微弱炎症が繰り返されていることが 知られている.この微弱炎症の指標となるのが角層 細胞より抽出される炎症性サイトカインの 1 つであ る IL-1RA/IL-1 である。この比は，UVB 曝露皮膚 角層や乾燥性皮膚の角層において高くなることが知 られている. ${ }^{14,15)}$

また，皮膚は常に酸化源に曝露されており容易に 酸化ストレスを受ける組織である。酸化ストレスと
は細胞内外において生成される活性酸素により開始 される細胞内あるいは細胞外成分が酸化されること により惹起されるストレスのことである．角層細胞 には酸化ストレスの最終生成物であるカルボニル夕 ンパク $(\mathrm{CP})$ が存在している。この角層内 $\mathrm{CP}$ は 皮膚保湿機能との関連性が報告されており，角層内 CP が多くなると皮膚表面水分量の低下と TEWL の上昇が生じる，角層内 $\mathrm{CP}$ の増加は，皮膚保湿機 能の低下と関係している. ${ }^{16)}$

\section{3. サクランの物理化学的性質 2}

サクランはその分子量から考え，被膜形成能が期 待される。そこで，サクラン水溶液を乾燥させ被膜 形成能を確認したところ，サクランに被膜形成能が 確認された。この被膜形成過程に化粧品製剂に汎用 されるポリオール類（アルキルジオール）を共存さ せることにより，水に対して難溶性のシートを形成 することが確認された。このシートは含水し水を保 持することからゲル状シート（gel sheet；GS） と名 付けた。 サクランとポリオールのゲル状シート形成 能は，ポリオールのアルキル鎖長と 2 つの水酸基の 置換位置とその混合比率に依存することが確認され た。ゲル状シート形成プロフィールを Fig. 1 に示 した.このプロフィールからわかるように，3つの 水酸基を構造内に持つグリセリンでは GS の形成が 確認されず，2つの水酸基を構造内に持つジオール 類に GS の形成能が確認された。ブタンジオールで は，2 つの水酸基の結合位置が 1 位と 2 位あるいは 1 位と 3 位では同様の広範囲のサクランとブタンジ オールの混合比率において同様の GS 形成は確認さ れたが，1 位と 4 位になると GS 形成は狭くなるこ とが確認された。 また，ジオールのアルキル鎖長が 3 から 6 に増えるにしたがって GS 形成領域が広く なることが確認された。

以上の結果から，GS 形成能を発揮するために必 要なポリオールの化学構造的特徵は以下のようにな る. ポリオールの水酸基は 2 つが必要であり, 水酸 基の結合位置はアルキル鎖の末端と隣接する 1 位と 2 位ジオール構造を有し，かつ，アルキル鎖長が適 度に長いことが必要であった。

\section{4. サクランーポリオールの乳化性能2)}

サクランとポリオールの水に難溶な GS の形成か ら考え，サクランとポリオールの混合体はある種の 組織体を形成し，その組織体内に親水性ドメインと 
1,2OH position of polyol

$\mathrm{C3}$

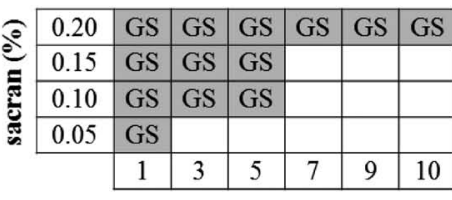

1,2-propanediol (\%)

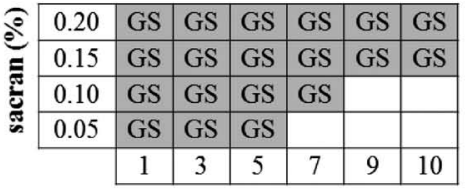

1,2-butanediol (\%)

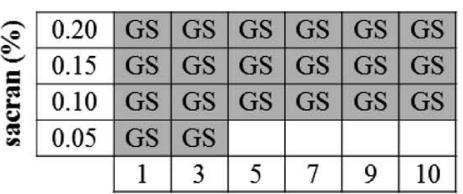

1,2-pentanediol (\%)

\begin{tabular}{|c|c|c|c|c|c|c|}
\hline 0.20 & GS & GS & GS & GS & GS & GS \\
\hline 0.15 & GS & GS & GS & GS & GS & GS \\
\hline
\end{tabular}

C6

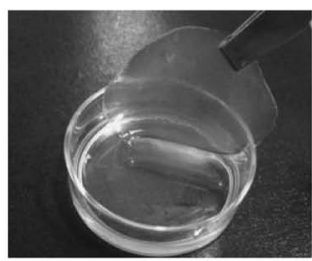

$0.5 \%$ Sacran $+20 \%$ 1,3-BG

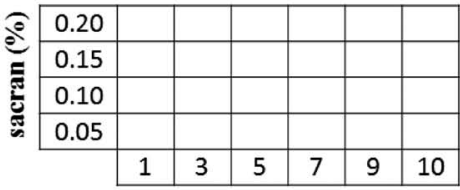

1,2,3-propanetriol (glycerin) (\%)
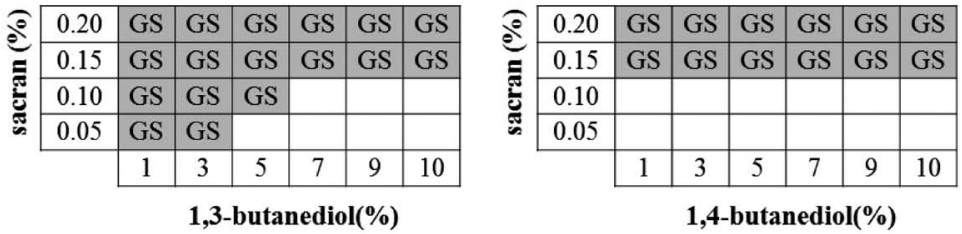

1,4-butanediol(\%)
Distance of hydroxyl

groups (Farther)

Fig. 1. Profiles of Sacran-Polyol Complexes the Gel-like Sheets Formations

Sacran-polyol aqueous solutions were allowed to dry over night by standing at $50^{\circ} \mathrm{C}$. Sacran-polyol aqueous solutions were prepared at concentrations from 0.05 to $0.2 \%$ for sacran and from 0 to $10 \%$ for polyols in water. The formation of gel sheet (GS) was identified as an insoluble sheet after re-immersed into water.

疎水性ドメインが存在する可能性が考えられる。こ の事実からサクランとポリオールの混合体には乳化 能が期待された。

そこで，サクランと各ポリオールの混合体の乳化 性能を，油性成分としてスクワランを用いて検証し た。 サクランと各ポリオールの混合体は $\mathrm{O} / \mathrm{W}$ エマ ルジョンを形成し，その結果を Fig. 2 に示した. サクランーポリオールの乳化は，乳化後の外観と粒 子サイズから確認した。 サクランとポリオールの乳 化性能は，GS 形成能と一致し，サクランとの混合 により乳化性能を発揮するポリオールは分子内に 2 つの水酸基を持つジオールであること，水酸基の結 合位置はアルキル鎖の末端と隣接する 1 位と 2 位で ありアルキル鎖長が適度に長いことが必要条件で あった.

この結果は，サクランとポリオールの組織体内に 親水性ドメインと疎水性ドメインを存在しているこ とを強く示唆し，疎水性ドメインの形成にはサクラ ンの構成糖の持つ硫酸基及びカルボキシル基に対す るポリオールの水酸基の水素結合の寄与が考えられ
た，そこで，サクランとポリオールの混合体による 乳化時の $\mathrm{pH}$ を酸性からアルカリ性に変化させたと ころ, 硫酸基及びカルボキシル基の解離が抑えられ る酸性 $\mathrm{pH}$ 領域において，乳化滴が大きくなる乳化 性能の低下が確認された（Fig. 3)。この事実から， サクランとポリオールの組織体内の疎水性ドメイン 形成においては水素結合の寄与が考えられ，Fig. 4 に示したような乳化様式が考えられた。

一般的に，乳化に必要な低分子界面活性剂はその 乳化能に由来する角層細胞間脂質ラメラ構造に影響 を及ぼすことにより皮膚一次刺激を惹起する可能性 が危惧されている，サクランとポリオールの混合体 による乳化は，界面活性剂を用いない製剂を提供す ることにより製剤による皮膚刺激性の軽減につなが ることが期待される.

5. 皮膚保護作用の観点から見たサクランーポリ オールにより形成された GS の機能

化粧品製剂に汎用される 1,3-ブタンジオールを用 いて調製した GS の物理化学的性質について皮膚保 護作用の観点から評価した。サクラン-1,3-ブタン 


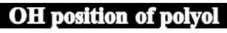

Distance of hydroxyl
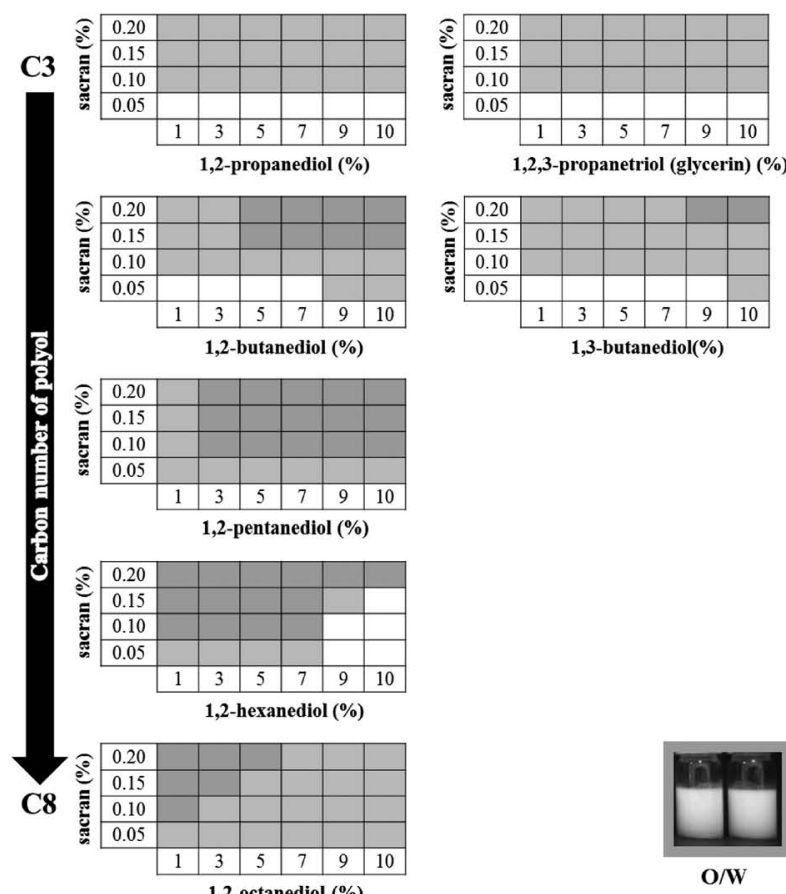

1,2,3-propanetriol (glycerin) (\%)
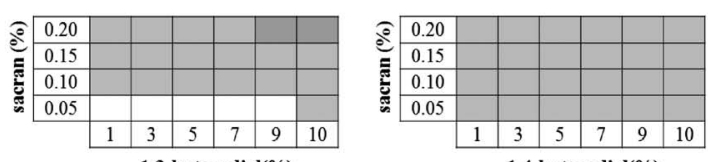

1,3-butanediol $(\%)$

1,4-butanediol(\%) groups (Farther)

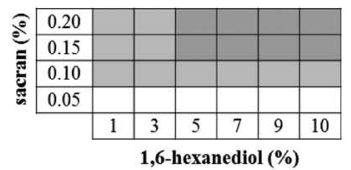

Fig. 2. Emulsification Profiles of Sacran-Polyol Complexes

Sacran original aqueous solution was prepared at a concentration of $0.25 \%$ by homogenizing with a homomixer (HM- 310 , AS ONE) for $1 \mathrm{~h}$ at $60^{\circ} \mathrm{C}$. Sacranpolyol complexes were prepared with polyol by pre-dispersion in the sacran original aqueous solution with the homomixer at $8000 \mathrm{rpm}$ for $10 \mathrm{~min}$ at room temperature or at $10000 \mathrm{rpm}$ for $10 \mathrm{~min}$ at $85^{\circ} \mathrm{C}$. Oils were mixed with the homomixer at $8000 \mathrm{rpm}$ for $15 \mathrm{~min}$ at room temperature or $10000 \mathrm{rpm}$ at $85^{\circ} \mathrm{C}$. Emulsification was evaluated as the appearance.

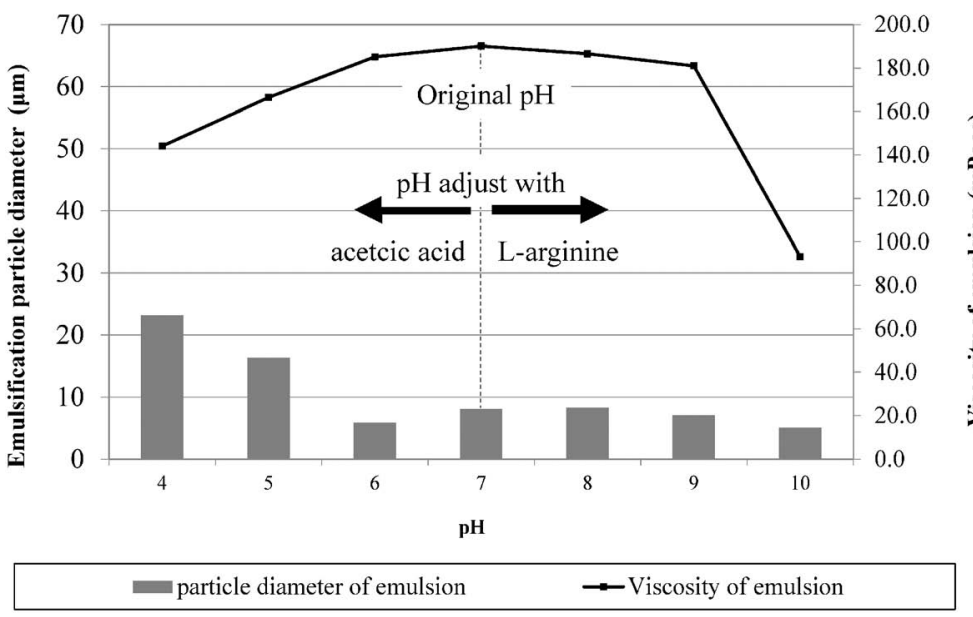

Fig. 3. Effect of $\mathrm{pH}$ on Emulsification of Sacran-Polyol Complex

The emulsification potentials of sacran-polyol complexes were examined in various $\mathrm{pH}$ conditions at room temperature. $0.25 \%$ sacran original aqueous solution was adjusted at range of $\mathrm{pH} 4$ to $\mathrm{pH} 11$ with $1.5 \%$ arginine aqueous solution and $1.5 \%$ acetic acid aqueous solution. The emulsification procedure was carried out in the same manner as described in Fig. 2. Effect of pH was evaluated with particle diameter and viscosity.

ジオールより調製した GS の皮膚内部からの水分の 蒸散に対する作用を明らかにするため, Fig. 5 に示 したシステムを用いて GS を透過する水分量につい て測定した。サクランのみで調製した GS に比較し てサクランと1,3-ブタンジオールを用いて調製した
GS は水分透過性を有意に抑制することが確認され た.

次に皮膚の外部からの化学物質の皮膚への浸透に 対する GS の作用を明らかにするためカルセインの 透過性を検討した。皮膚の代替膜として羊毛のケラ 


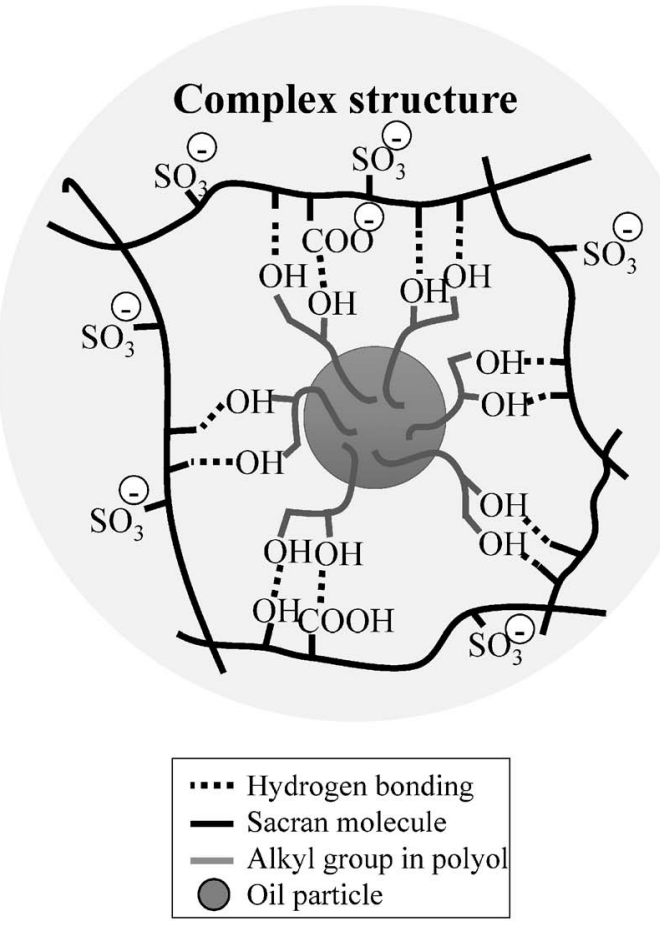

Fig. 4. The Expected Mechanism of the Emulsification Using Sacran-Polyol Complex Aqueous Solution

チンタンパクより再生したケラチンフィルムを用 い, ${ }^{17)}$ ケラチンフィルム上に GS を調製し，その上 部よりカルセイン溶液を添加した。 カルセインの GS 透過は，サクランのみで調製した GS に比較し てサクランと 1,3-ブタンジオールを用いて調製した GS のほうが有意に低いことが確認された（Fig. 6)。これらの結果をまとめると, 皮膚表面において サクランとポリオールにより調製された GS が形成
されることにより皮膚内部からの水分蒸散と皮膚外 部からに化学物質の皮膚内部への侵入を抑制する作 用が期待された。

\section{AD 罹患歴のある健常人の皮膚機能に対する} サクラン配合製剤の効果 ${ }^{3}$

$\mathrm{AD}$ はアレルギー性の皮膚疾患であり，バリア病 とも呼ばれている，健常人と比較して $\mathrm{AD}$ 患者は 低い表皮バリア機能を示す。近年の研究では，AD 患者には高い比率でフィラグリン遺伝子の不全が確 認されており，フィラグリンの低下が表皮バリア機 能の 1 つの原因として考えられている. ${ }^{18)}$

これまでにサクランとポリオールの複合体は含水 GS を形成し，その GS にはバリアとして高い機能 を有する物理化学的特性が見い出されている. ビオ チン化サクラン及びビオチン化サクランーポリオー ル複合体を再生表皮モデル上に処理し，皮膚内の局 在について蛍光標識ストレプトアビジンを用いて確 認したところ，角層表面に局在することが確認され た（未発表データ）。皮膚表面においても，サクラ ンは GS を形成し，バリアとして働く可能性が期待 された.

そこで， $0.04 \%$ のサクランと $15 \%$ のポリオール 類を配合した製剂を調製し，その製剤のスキンケア 効果を $\mathrm{AD}$ 罹患歴のある健常人 9 名に対する 1 力 月間の連用試験において評価した。残念ながら，皮 膚表面水分量及び TEWL の各々については有意な 効果はサクラン配合製剤には確認されなかった。近 年，筆者らは皮膚保湿機能表現するパラメーターと

(a)

(b)

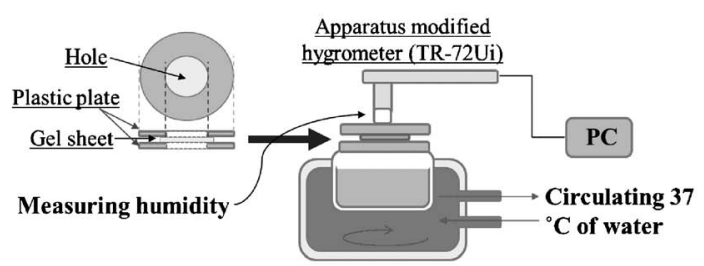

\begin{tabular}{|l|c|c|c|}
\hline \multirow{2}{*}{} & Water evaporation rate & \multicolumn{2}{|c|}{ Significance } \\
\cline { 3 - 4 } & $\begin{array}{c}\text { (\%/min }) \\
\text { vs Control }\end{array}$ & $\begin{array}{c}\text { vs } 0.5 \% \\
\text { Sacran }\end{array}$ \\
\hline Control & $1.24 \pm 0.02$ & & \\
\hline $0.5 \%$ Sacran & $1.04 \pm 0.06$ & $* * *$ & $* * *$ \\
\hline $0.5 \%$ Sacran $+20 \% 1,3-\mathrm{BG}$ & $0.17 \pm 0.05$ & $* * *$ & $* * *$ \\
\hline
\end{tabular}

Fig. 5. Water Evaporation through Gel-like Sheets of Sacran or Sacran-1,3-Butanediol (1,3-BG) Complex

The water evaporation was measured with the apparatus modified hygrometer (a). The gel sheet was sandwiched between the plastic plates with hole. This sandwiched plate was set tightly on the bottle which was filled up with water. The water in the bottle was maintained at constant temperature by circulation of water controlled at $37^{\circ} \mathrm{C}$. The water evaporation was measured as the change of humidity in hygrometer through the sandwiched plate for 60 min with 1 min interval. (b) Results were expressed mean \pm S.D. of rate of the change of humidity. Student $t$-test. ${ }^{* * *} p<0.001$. 


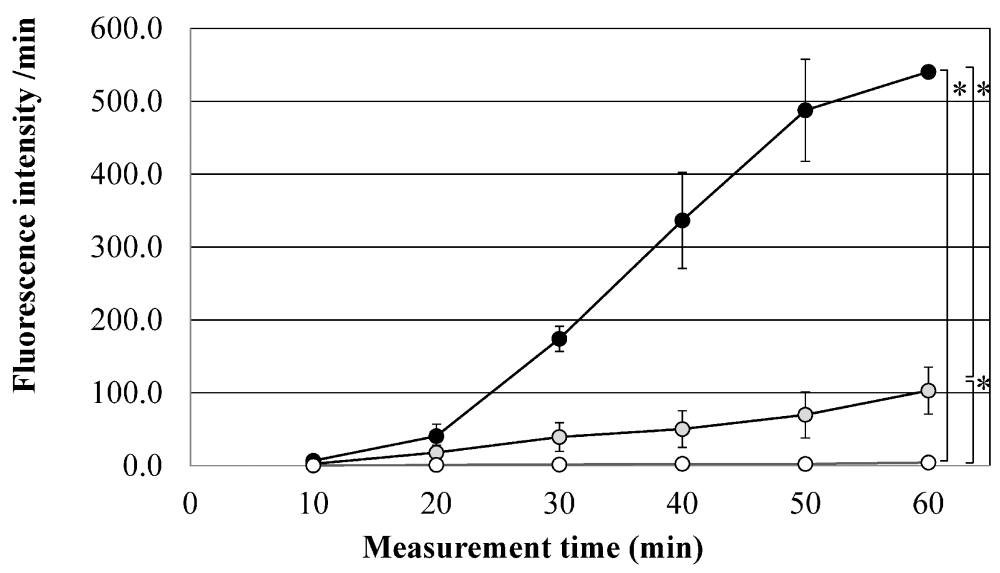

$\rightarrow$ Control $\quad-0-0.5 \%$ Sacran $\quad-0-0.5 \%$ Sacran $+20 \% 1,3-\mathrm{BG}$

Fig. 6. Permeability of a Calcein through Gel-sheets of Sacran or Sacran-1,3-Butanediol (1,3-BG) Complex

The keratin film was pasted on the bottom of plastic tube, $2 \mathrm{~cm}$ height and $5 \mathrm{~mm}$ diameter, respectively. $200 \mu \mathrm{L}$ of $0.5 \%$ sacran aqueous solution or $0.5 \%$ sacran aqueous solution containing $20 \% 1,3-\mathrm{BG}$ was placed on the keratin film of the plastic tube, and dried over night at $50^{\circ} \mathrm{C}$ to be stacked on the keratin film. 300 $\mu \mathrm{L}$ of $1 \mathrm{mmol} / \mathrm{L}$ calcein aqueous solution was placed in the tube. The tube was set in a well of 48-well plate filled with PBS without $\mathrm{Mg}^{2+}$ and $\mathrm{Ca}^{2+}\left(\mathrm{PBS}^{-}\right)$. The leakage of calcein through the bottom of the vessels was monitored with the fluorescent measurements (Ex/Em: $495 / 520 \mathrm{~nm}$ ) at $10 \mathrm{~min}$ interval for $60 \mathrm{~min}$ at $37^{\circ} \mathrm{C}$. Student $t$-test. ${ }^{*} p<0.05$.

して皮膚表面水分量（skin surface water content; SWC）を TEWL で規格化した值（SWC/TEWL） の有用性について報告している. ${ }^{19)}$ 本結果を, SWC/TEWL にて解析したところ， サクラン配合 製剂の使用により有意に皮膚保湿機能の改善が確認 された（Fig. 7)

さらに，サクラン配合製剤の使用による角層パラ メーターの改善作用が確認された。まず，角層細胞 面積であるが，プラセボ製剤において変化は確認さ れなかったが，サクラン配合製剤において有意に大 きくなることが確認された [Fig. 8(a)]。一般的に 皮膚内部において炎症反応が惹起されている場合, 皮膚表面の角層細胞面積は小さくなる．実際に炎症 パラメーターである IL-1RA/IL-1 $\alpha$ についても，サ クラン配合製剤の連用において有意に低下すること が確認されている [Fig. 8(e)]。この2つのパラ メーターを合わせて考えると，サクラン配合製剤の 連用により皮膚内部での炎症状態が軽減された可能 性が示唆される。

次に, 皮膚乾燥時に頻繁に観察される多重剥離に ついてもサクラン配合製剤の連用により減少するこ とが確認された [Fig. 8(b)]。この結果は，サクラ ン配合製剤による皮膚保湿機能の改善に由来する可 能性が示唆される.

さらに，角層細胞の成熟度，角層細胞の $\mathrm{CE}$ の成 熟度を示す $\mathrm{SH} / \mathrm{SS}$ とインボルクリン/ナイルレッ
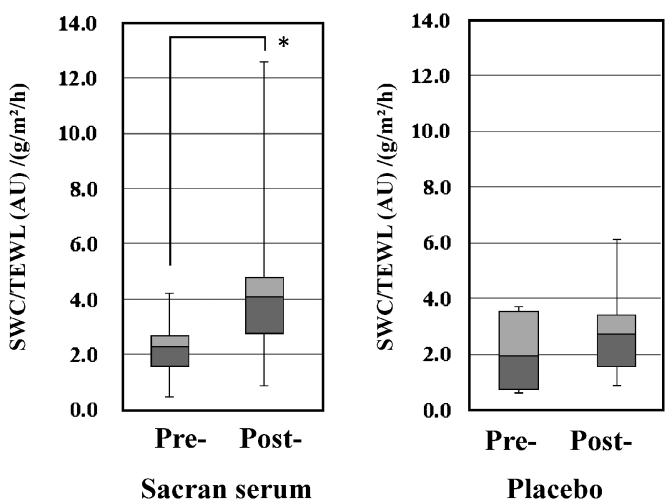

Fig. 7. Effects of Sacran-serum on ratios of Skin Surface Water Content (SWC) and Trans-epidermal Water Loss (TEWL)

The sample, sacran-serum, and the placebo were topically applied on each inner forearm (a left-right comparison study) every morning and night for four weeks. SWC and TEWL were evaluated at pre- and post- application of each treatment. Changes in ratio of SWC and TEWL in volunteers applying samples, serum and placebo for 4 weeks (pre: baseline of testing sites, post: after 4 weeks' application). Wilcoxon rank sum test, ${ }^{*} p<0.05$.

ドについてもサクラン配合製剤連用により有意な改 善が確認された [Figs. 8(c) and (d)]。剥離角層を 湿潤環境内でインキュベートすることにより $\mathrm{SH} /$ $\mathrm{SS}$ の低下及び CE の成熟が確認されている（未発 表デー夕)。これらの事実は角層細胞の成熟及び $\mathrm{CE}$ の形成には適正な角層水分量の維持が重要な因 子として考えられる。

また，角層細胞内 CP の減少もサクラン配合製剂 連用により確認されたことから，表皮内酸化状態の 軽減も示唆された $[\mathrm{Fig} .8$ (f) ]. 表皮内酸化状態は 
(a)

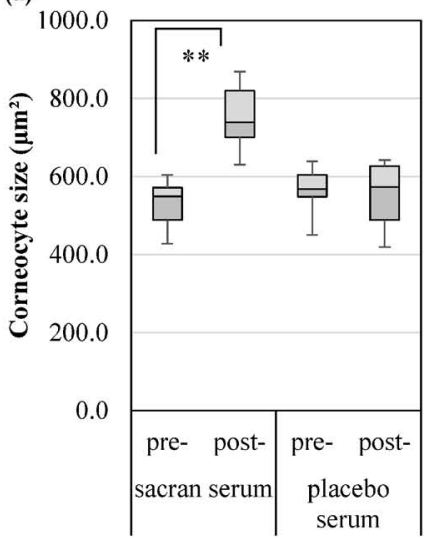

(d)

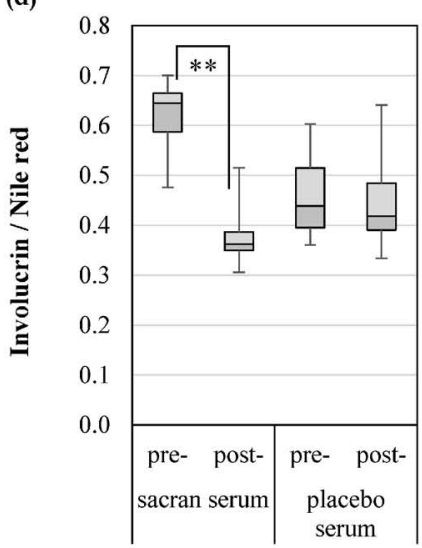

(b)

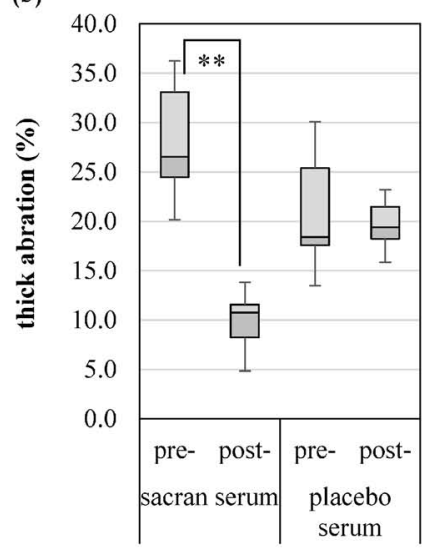

(e)

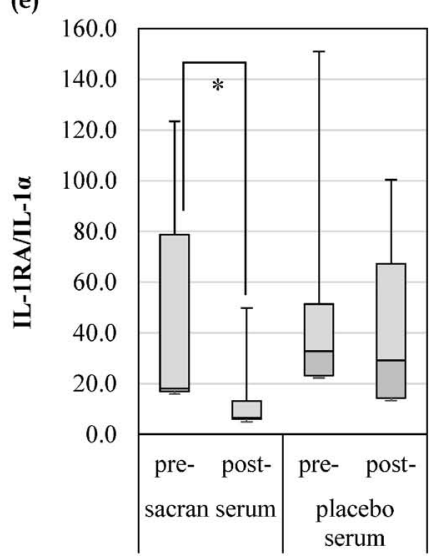

(c)

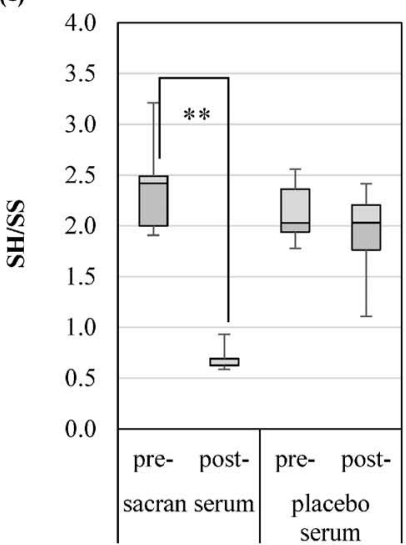

(f)

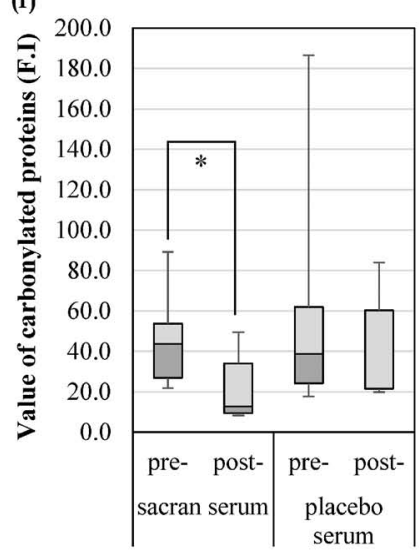

Fig. 8. Effects of Sacran-serum on Parameters of Corneocytes

The sample, sacran-serum, and the placebo were topically applied on each inner forearm (a left-right comparison study) every morning and night for four weeks. Parameters of corneocytes collected using the tape stripping method were evaluated at pre- and post- application of each treatment for (a) changes in mean size of corneocytes. (b) changes in percentage of thick abrasion of corneocytes, (c) changes in ratio of SH to SS, (d) Changes in immunostainability of involucrin normalized with Nile red fluorescence, (e) changes in ratio of IL-1RA to IL-1 $\alpha$, (f) changes in protein carbonylation in corneocytes. Wilcoxon rank sum test, ${ }^{*} p<$ $0.05,{ }^{*} p<0.01$.

皮膚の乾燥の程度により充進することが確認されて いる。冬期の乾燥性皮膚では角層内に CP が多くな ること，再生表皮モデルの表面を乾燥することに よっても表皮全層に高いCP が観察されている。 サ クラン配合製剤には皮膚保湿機能を改善することに より角層細胞が成熟する環境を整えて, 高酸化状態 となる環境を改善している可能性が示唆される.

\section{7. サクランのスキンケア効果}

これまでのサクランの物理学的特性及びヒト皮膚 への連用による皮膚状態の解析結果を総合的に考察 するとサクランのスキンケア効果の本質は以下のよ うに考察される. サクランは角層表面において含水 ゲル状のシートを形成する。このとき, ポリオール が共存することにより，その効果は強くなる．ゲル 状シー卜は皮膚内部からの水分の蒸散及び環境から の種々の因子，成分の皮膚内部への侵入あるいは刺 激を妨げる。この効果により表皮が本来の分化過程
が適正に進行でき得る環境を提供している可能性が 考えられた。

以上のことから，サクランは皮膚表面で保護膜を 形成し，表皮本来が正常な分化を営む環境を提供す る.これが，サクランのスキンケア効果の本質では ないかと考える。

利益相反土井萌子（大東化成工業株式会社の 社員).

\section{REFERENCES}

1) Okajima M. K., Bamba T., Kaneso Y., Hirata K., Fukusaki E., Kajiyama S., Kaneko T., Macromolecules, 41, 4061-4064 (2008).

2) Doi M., Sagawa Y., Mizutani T., Okano Y., Momose S., Tanaka T., Masaki H., J. Soc. Cosmet. Chem. Jpn., 51, 117-125 (2017). 
3) Doi M., Sagawa Y., Momose S., Tanaka T., Mizutani T., Okano Y., Masaki H., J. Dermatol., 44, 1360-1367 (2017).

4) Eckert R. L., Yaffe M. B., Crish J. F., Murthy S., Rorke E. A., Welter J. F., J. Invest. Dermatol., 100, 613-617 (1993).

5) Stewart M. E., Downing D. T., J. Lipid Res., 42, 1105-1110 (2001).

6) Kurasawa M., Maeda T., Oba A., Yamamoto T., Sasaki H., Biochem. Biophys. Res. Commun., 406, 506-511 (2011).

7) Denecker G., Hoste E., Gilbert B., Hochepied T., Ovaere P., Lippens S., Van den Broecke C., Van Damme P., D'Herde K., Hachem J. P., Borgonie G., Presland R. B., Schoonjans L., Libert C., Vandekerckhove J., Gevaert K., Vandenabeele P., Declercq W., Nat. Cell Biol., 9, 666-674 (2007).

8) Choi H. K., Cho Y. H., Lee E. O., Kim J. W., Park C. S., Arch. Dermatol. Res., 309, 795803 (2017).

9) Hoath S. B., Leahy D. G., J. Invest. Dermatol., 121, 1440-1446 (2003).

10) Caubet C., Jonca N., Brattsand M., Guerrin M., Bernard D., Schmidt R., Egelrud T., Simon M., Serre G., J. Invest. Dermatol., 122, 1235-1244 (2004).

11) Horikoshi T., Igarashi S., Uchiwa H., Brysk
H., Brysk M. M., Br. J. Dermatol., 141, 453459 (1999).

12) Hashimoto Y., Suga Y., Matsuba S., Mizoguchi M., Takamori K., Seitz J., Ogawa H., Arch. Dermatol. Res., 292, 570-572 (2000).

13) Hirao T., Int. J. Cosmet. Sci., 25, 245-257 (2003).

14) Hirao T., Aoki H., Yoshida T., Sato Y., Kamoda H., J. Invest. Dermatol., 106, 11021107 (1996).

15) Terui T., Hirao T., Sato Y., Uesugi T., Honda M., Iguchi M., Matsumura N., Kudoh K., Aiba S., Tagami H., Exp. Dermatol., 7, 327334 (1998).

16) Fujita H., Hirao T., Takahashi M., Skin Res. Technol., 13, 84-90 (2007).

17) Katoh K., Shibayama M., Tanabe T., Yamauchi K., Biomaterials, 25, 2265-2272 (2004).

18) Polcari I., Becker L., Stein S. L., Smith M. S., Paller A. S., Pediatr. Dermatol., 31, 489-492 (2014).

19) Masaki H., Yamashita Y., Kyotani D., Honda T., Takano K., Tamura T., Mizutani T., Okano Y., J. Cosmet. Dermatol., 18, 308-314 (2019). 